\title{
Foreign Investments and the Rule of Law
}

\author{
Charmen Loh $^{1}$ \\ ${ }^{1}$ Department of Economics and Finance, College of Business Administration, Rider University, Lawrenceville, \\ NJ, USA \\ Correspondence: Charmen Loh, College of Business Administration, Rider University, 2083 Lawrenceville Rd, \\ Lawrenceville, NJ, USA. Tel: 1-609-895-5508. E-mail: loh@rider.edu
}

Received: April 22, 2015

Accepted: May 11, 2015

Online Published: June 25, 2015

doi:10.5539/ijef.v7n7p116

URL: http://dx.doi.org/10.5539/ijef.v7n7p116

\begin{abstract}
This paper attempts to answer two questions. First, is foreign investment good for the host country? Second, what factors are associated with greater foreign investments? To answer the first question, this study calculates the global stock market integration scores of a sample of 41 countries, and it finds that this integration is associated with greater per capita income, stronger growth in income, and higher levels of natural capital and produced capital. In addressing the second question, this study finds that the risk-adjusted return does not influence the foreign investment decision; rather, it is the rule of law-the host country's ability to ensure the safety and mobility of foreign capital-that is the primary driving force for foreign investments.
\end{abstract}

Keywords: stock market integration, rule of law, governance, wealth

\section{Introduction}

Finance researchers have, by now, established that the ability to invest in foreign markets benefits international investors by allowing for a greater diversification of their unsystematic risk (Note 1). Bailey and Stultz (1990), for instance, conclude that US investors can reduce their portfolio risk by up to $50 \%$ simply by adding Asian stocks to their portfolios.

What is less clear is the impact of foreign investments on the host country. Although a number of researchers have concluded that this inward flow of capital is beneficial to the host countries, this is not a consensus view (Note 2). A number of these studies have focused on the capital market liberalization and its impact on the host country (Note 3). Billmeier and Massa (2009) examine the quality of institutions and remittances from residents who work overseas and conclude that they contribute significantly to stock market development. Anecdotally, we have read news about countries taking measures to promote foreign investments (Note 4). The often-cited reasons include gain in foreign technological know-how and business practices, less isolation from the rest of the world and greater economic ties with other countries, reduction in the cost of capital and increases in output, stock market liquidity (Note 5), and greater adherence to governance (Note 6).

But we have also seen cases where countries have decided to take the opposite approach-putting tighter controls on foreign capital and nationalizing foreign investments. They cite a number of threats-greater stock market volatility, vulnerability to manipulation by outsiders, and infringement to their sovereignty-as some of the reasons for restricting foreign investments.

So, we are not truly sure if the inflow of capital is good or bad. And if it is good, in what way and to what extent is it good? This study addresses the wealth effect of foreign investment in a systematic and scientific approach. It uses of a large sample of countries, covers an extended period, to analyze the effect on a number of wealth measures, as recognized and used by the World Bank.

The present study is different from liberalization studies in that liberalization implies a willingness on the part of the host country to accept foreign capital. But this willingness does not necessarily mean that foreign capital will arrive. Integration offers a more direct measure of the movement of foreign capital in that it implies that foreign capital is already at work in the host country.

To measure the level of foreign investments, we use the stock market integration score. First suggested by Akdogan (1996), this measure has been used by a number of researchers in their studies of international investments (Note 7). 
We sort the Akdogan integration score of 41 countries that have well-functioning stock markets into three portfolios (Note 8). We find that countries whose stock markets are highly integrated have substantially higher gross national income, income growth, natural capital, and produced capital. On one measure, the per capita income, for instance, we find that a one standard deviation increase in stock market integration-roughly from China to Mexico-results in an increase of \$7,300 (Year, 2000) in per capita income. One additional finding: we notice that countries with the highest degree of integration-those in the high-integration portfolio-are doing especially well (in the order of 100 to 300 percent) in all the wealth measures.

Having established that integration is positively associated with wealth, the study next examines the country-specific characteristics that are related to a country's level of integration. We can study this by posing a question: what raises a country's stock market integration? Integration comes about as a result of foreigners' willingness to invest in that country. There are two conditions that determine this willingness. One, can they benefit-in the form of increased return and/or reduced risk-by investing in a foreign country? Two, how safe is their money and can they take their money out of the country?

We content that the first condition, the risk-adjusted return, is not sufficient for foreign investment. For foreign capital to enter a country, the second and necessary condition-the safety and mobility of capital-must be present, because if an investor is unsure if his investment in a foreign country is secure, no amount of risk reduction and high return can persuade him to invest in the country (Note 9).

Although development economists have proposed many factors to measure the safety and mobility of foreign capital, the often-used proxy is the rule of law indicator published by the World Bank (Note 10). When we regress the integration score of the 41 countries against this rule of law indicator, we find that the integration is positively associated with rule of law. In contrast, when we regress the integration score against the risk-adjusted return (the Sharpe Index), we find no significant association. Taken together, these findings support our contention that it is the rule of law-not the risk-adjusted return-that attracts foreign investments.

This paper contributes in a couple ways to the existing literature. First, it furthers the understanding of the impact of foreign investment on the host country by adding a new dimension-wealth-to the existing list of benefits.

Second, it finds that foreign investors are concerned only with the safety and mobility of their capital. Risk and return do not enter into their decision process. This finding carries important policy implications for countriesespecially the emerging ones-that focus the potentially high returns as their key selling point to foreign investors. This paper suggests that this focus may be misplaced. They would attract more foreign capital if they instead focus on improving and reforming their institutions and governance.

The rest of the paper is organized as follows: Section 2 covers a discussion of the research methodology. Specifically, it discusses the derivation of the stock market integration score. In Section 3, we will detail the data collection procedure. Results are presented in Section 4. And Section 5 summarizes the main findings and major conclusions.

\section{Methodology}

The global market integration score used in this study is based on Akdogan (1996), who proposes a method of decomposing the international risk measure. The calculation of the integration score starts with the one-factor regression between a country's return and the global market benchmark.

$$
R_{i}=\alpha_{i}+\beta_{i} R_{g}+\varepsilon_{i}
$$

Where $R_{i}$ represents a country $i$ 's index returns and $R_{g}$ is the benchmark global index returns, $\varepsilon_{\mathrm{i}} \mathrm{s}$ a random error term with $E\left(\varepsilon_{\mathrm{i}}\right)=0$. The return for country $i$ during period $t$ is calculated as follows:

$$
R_{i, t}=\log \left(p_{i, t} / p_{i, t-1}\right)
$$

The variance resulting from the regression for country $i$ can be decoupled into two components:

$$
\operatorname{var}\left(R_{i}\right)=\beta_{i}^{2} \operatorname{var}\left(R_{g}\right)+\operatorname{var}\left(\varepsilon_{i}\right)
$$

Dividing both sides of the equation by $\operatorname{var}\left(R_{i}\right)$ yields the following,

$$
\begin{gathered}
\left.1=\beta_{i}{ }^{2} \operatorname{var}\left(R_{g}\right) / \operatorname{var}\left(R_{i}\right)+\operatorname{var}\left(\varepsilon_{i}\right)\right) / \operatorname{var}\left(R_{i}\right) \\
1=p_{i}+q_{i}
\end{gathered}
$$

where,

$$
q_{i}=\operatorname{var}\left(\varepsilon_{i}\right) / \operatorname{var}\left(R_{i}\right)
$$

The integration score that we will use for this study is $p_{i}$. It is a measure of country $i$ 's contribution to the world 
systematic risks. The other term, $q_{i}$, is a measure of country $i$ 's idiosyncratic risk.

\section{Data}

The data that we use for the calculation of stock market integration are gathered from Datastream. The study period is from 1985 to 2000 . The global benchmark we used for the calculation of stock market integration is the Datastream worldwide index. The various wealth measures are derived from a study by the World Bank Institute.

Table 1 presents information on the integration scores in three portfolios, as well as a population. For the 41 countries in the world with stock markets, the average integration score is 0.1787 , with a range of 0.0002 to 0.5095 . The standard deviation is 0.0789 .

For the purpose of studying the association between market integration, we form three portfolios sorted by the integration score. Low-integration portfolio consists of 14 countries that are the least integrated with the world markets. The mean integration score for this group is 0.0201 , with a minimum of 0.0002 to a high of 0.0557 .

The next portfolio-the mid-integration group-contains 13 countries that have an average integration score of 0.1599 . The minimum-to-maximum range is 0.0584 to 0.2421 .

The third portfolio is made up of 14 countries whose stock markets are highly integrated to that of the global market. This group has an average integration score of 0.3547 , and the lowest in the group has a score of 0.2518 and the highest 0.5095 .

Table 1. Integration score statistics of the three portfolios and the total sample

\begin{tabular}{lcccccc}
\hline Portfolio sorted by integration & Mean & Median & Standard Deviation & Maximum & Minimum & Observations \\
\hline Low-integration & 0.0201 & 0.0162 & 0.0191 & 0.0557 & 0.0002 & 14 \\
Mid-integration & 0.1599 & 0.163 & 0.0575 & 0.2421 & 0.0584 & 13 \\
High-integration & 0.3547 & 0.3357 & 0.0789 & 0.5095 & 0.2518 & 14 \\
Total & 0.1787 & 0.163 & 0.1513 & 0.5095 & 0.0002 & 41 \\
\hline
\end{tabular}

The countries that comprise the three portfolios are listed below

\begin{tabular}{ll}
\hline Portfolio & Countries \\
\hline Low-integration & India, Israel, China, Philippines, Sri Lanka, Denmark, Turkey, Jordan, Indonesia, Switzerland, Greece, Romania, \\
& Brazil, Colombia \\
Mid-integration & Hungary, France, Chile, Thailand, South Africa, Malaysia, Mexico, Portugal, Italy, Russia, Sweden, Australia, Korea \\
High-integration & Germany, Bangladesh, Belgium, Argentina, Netherlands, Singapore, Austria, Ireland, UK, Spain, Norway, Canada, \\
& US, Japan \\
\hline
\end{tabular}

Table 2 breaks down the three portfolios by income group, as established by the World Bank. As the table indicates, the low-integration portfolio has eight countries in the Lower Middle income group, representing 57.1\% of the group. It also has four countries in the high-income group.

Table 2. The three portfolios and income grouping

\begin{tabular}{lllll}
\hline \multirow{2}{*}{ Portfolio Sorted by Integration Score } & \multicolumn{4}{l}{ Income Group } \\
\cline { 2 - 5 } & High & Upper Middle & Lower Middle & Low \\
\hline Low-integration & 4 & 1 & 8 & 1 \\
& $28.60 \%$ & $7.10 \%$ & $57.10 \%$ & $7.10 \%$ \\
Mid-integration & 6 & 6 & 1 & 0 \\
& $46.20 \%$ & $46.20 \%$ & $7.70 \%$ & $0.00 \%$ \\
High-integration & 11 & 2 & 0 & 1 \\
& $78.60 \%$ & $14.30 \%$ & $0.00 \%$ & $7.10 \%$ \\
\hline
\end{tabular}

The mid-integration portfolio shows a slow migration up the income group, with six countries each in the high and upper middle-income groups. There is one lower income country in this group and none in the low-income category.

The high-integration portfolio is overwhelmingly represented by high-income countries, making up 11 out of the 
14 countries (78.6\%). It has two upper middle-income countries and one low income country.

Taken together, it suggests that the level of global integration is related in a positive way to the income level of the countries.

Table 3 contains information on the geographic location / OECD membership of countries in the three portfolios. The low integration group is quite evenly distributed across the various regions around the world, with one country from the Middle-east North Africa, two countries each coming from Latin America Caribbean, Europe Central Asia, and South Asia, three from East Asia Pacific, and four from OECD.

Table 3. Integration by geographic location/organization

\begin{tabular}{|c|c|c|c|c|c|c|c|c|}
\hline Portfolio Sorted by Integration Score & LAC & ECA & MNA & AFR & SAS & EAP & OECD & Total \\
\hline \multirow[t]{2}{*}{ Low-integration } & 2 & 2 & 1 & 0 & 2 & 3 & 4 & 14 \\
\hline & $14.30 \%$ & $14.30 \%$ & $7.10 \%$ & $0.00 \%$ & $14.30 \%$ & $21.40 \%$ & $28.60 \%$ & $100.00 \%$ \\
\hline \multirow[t]{2}{*}{ Mid-integration } & 2 & 2 & 0 & 1 & 0 & 3 & 5 & 13 \\
\hline & $15.40 \%$ & $15.40 \%$ & $0.00 \%$ & $7.70 \%$ & $0.00 \%$ & $23.10 \%$ & $38.50 \%$ & $100.00 \%$ \\
\hline \multirow[t]{2}{*}{ High-integration } & 2 & 0 & 0 & 0 & 1 & 0 & 11 & 14 \\
\hline & $14.30 \%$ & $0.00 \%$ & $0.00 \%$ & $0.00 \%$ & $7.10 \%$ & $0.00 \%$ & $78.60 \%$ & $100.00 \%$ \\
\hline
\end{tabular}

Note. $\mathrm{LAC}=$ Latin America and Caribbean; ECA = Europe and Central Asia; MNA = Middle-east and North Africa; AFR = Sub-Sahara Africa; SAS = South Asia; EAP = East Asia and Pacific; OECD = Organization for Economic Co-operation and Development.

The mid-integration group shows that there are five (or 38.5\%) countries that belong to the OECD, an organization that is made up of high-income, developed economies. There are three countries from the East Asia Pacific region, and two each from Latin America Caribbean and Europe Central Asia regions.

The high-integration portfolio is most notable for the large number of countries-eleven (or 78.6\%)-that are members of the OECD. The large representation in a high-income organization is consistent with the view that global stock market integration is positively related to the income of a country. The high-integration group also contains two countries from Latin America Caribbean and one from South Asia region.

\section{Results}

\subsection{Integration and Wealth}

Table 4. Integration and the wealth of nations

\begin{tabular}{|c|c|c|c|c|}
\hline Portfolio Sorted by Integration Score & Gross National Income & $\begin{array}{l}\text { Growth in Gross National } \\
\text { Income }\end{array}$ & Natural Capital & $\begin{array}{l}\text { Produced } \\
\text { Capital }\end{array}$ \\
\hline & A. Means & & & \\
\hline Mid-integration & 10,272 & 1,064 & 8,217 & 29,027 \\
\hline High-integration & 20,380 & 2,771 & 11,471 & 64,930 \\
\hline Low-integration vs. mid-integration & $-2,429$ & -45 & $-4,040 * *$ & $-7,417$ \\
\hline Mid-integration vs. high-integration & $-10,108^{* *}$ & $-1,706 * *$ & $-3,255$ & $-35,903^{* * *}$ \\
\hline Low-integration vs. high-integration & $-12,537 * * *$ & $-1,751 * *$ & $-7,295^{*}$ & $-43,319 * * *$ \\
\hline
\end{tabular}

Note. Produced capital is the sum of machinery, equipment, and structures (including infrastructure). Natural capital is the sum of nonrenewable resources (including oil, natural gas, coal, and mineral resources), cropland, pastureland, forested areas (including areas used for timber extraction and nontimber forest products), and protected areas. * significant at the 0.10 level, ** significant at the 0.05 level, *** significant at the 0.01 level.

Table 4 presents the results of the analysis of integration with the various measures of wealth. On gross national income, the average for the low-integration portfolio is $\$ 7,843$ per year, $\$ 10,272$ for mid-integration portfolio, and $\$ 20,380$ for the high-integration group. While there is a nominal difference in GNI between the low-integration and mid-integration group, the difference is not statistically significant. But when the GNI figures from the low-integration and mid-integration countries are compared against the high-integration group, the differences are large and significant. Residents of high-integration countries earn on average $\$ 10,108$ more 
the residents of mid-integration countries. They earn $\$ 12,537$ more than their counterparts in the low-integration countries.

The next column shows the annual growth in per capita income for the three portfolios. For the low-integration countries, the growth is $\$ 1,019$ per year. For the mid-integration portfolio, the average increase in wealth is $\$ 1,064$. The high-integration countries experience the largest expansion in income, at an average of $\$ 2,771$ per person per year.

When we conduct pair-wise comparison of the three portfolios, our results show that there is virtually no difference between the low-integration and the mid-integration portfolios. Inter-portfolio differences become evident only when we compare the low-integration and mid-integration portfolio to the high-integration portfolios. High-integration residents out-earn their counterparts in mid-integration countries by $\$ 1,706$ and in low-integration countries by $\$ 1,751$.

The column on the natural capital per capita indicates that the three portfolios are differently endowed, showing a pattern that suggests a positive relationship between integration and natural capital. The low-integration countries, for instance, have an average natural capital of $\$ 4,177$ per capita, mid-integration possesses an average of $\$ 8,217$, and the high-integration owns an average natural capital of $\$ 11,471$. Inter-portfolio comparison indicates significance only between low-integration and mid-integration (mean difference of $-\$ 4,040$, significant at the 0.05 level) and between low-integration and high-integration, with a difference of $-\$ 7,295$ (significant at a 0.10 level).

Figures on produced capital per person follow a familiar pattern of greater levels of wealth-in this case, produced capital-for countries with higher degree of integration. On the basis of individual portfolios, the low-integration has an average of \$21,611 per capita, the mid-integration produces an average \$29,027 in capital, and the high-integration countries register an average of $\$ 64,930$ in produced capital.

Pair-wise comparison of the portfolios shows that there is no statistically significant difference between the low-integration portfolio and the mid-integration portfolio, although nominally the difference of $-\$ 7,417$ is quite sizable. The biggest difference in produced capital, as in the case of GNI and GNI growth, is between the high-integration and the other two lower integration groups. Specifically, the 14 high-integration countries have an average \$35,903 greater produced capital than the mid-integration countries. And these same countries produce an average of $\$ 43,319$ per person more in capital than the low-integration countries.

\subsection{Integration and the Rule of Law}

The second part tests the proposition that it is the rule of law-not the risk-adjusted return-that is the primary driving force behind an investor's decision to enter a foreign country. Table 5 details the results of the OLS regression analysis. The first regression examines the connection between global integration and the Sharpe Index, a measure of a country's risk-adjusted return. The results show that there is no statistically significant association between the two variables. The coefficient for Sharpe Index is 0.0910 ( $p$-value is 0.5620).

Table 5. Ordinary least squares regressions: cross section of 41 countries

\begin{tabular}{|c|c|c|}
\hline \multirow[b]{2}{*}{ Independent Variables } & \multicolumn{2}{|c|}{ Dependent Variable } \\
\hline & Global Market Integration & Global Market Integration \\
\hline \multirow[t]{2}{*}{ Rule of Law } & & 0.0838 \\
\hline & & -0.0222 \\
\hline \multirow[t]{2}{*}{ Sharpe Index } & 0.091 & \\
\hline & -0.1556 & \\
\hline \multirow[t]{2}{*}{ Intercept } & 0.1737 & 0.1162 \\
\hline & -0.0253 & -0.0263 \\
\hline Observations & 41 & 41 \\
\hline Adj. $R^{2}$ & -0.0167 & 0.2489 \\
\hline$F$ & 0.34214 & 14.2577 \\
\hline p-Value & 0.561966 & 0.00053 \\
\hline
\end{tabular}

Note. Standard errors are in parentheses.

Global market integration $=p_{i}=\beta_{i}{ }^{2} \operatorname{var}\left(R_{g}\right) / \operatorname{var}\left(R_{i}\right)=$ a measure of country $i$ 's contribution to the world systematic risks. 
Rule of law = an indicator that measures "perceptions of the extent to which agents have confidence in and abide by the rules of society, and in particular the quality of contract enforcement, property rights, the police, and the courts, as well as the likelihood of crime and violence." (Note 11).

The second regression examines the relationship between the global integration and the rule of law. The rule of law indicator serves as a proxy for the safeguard of property rights-foreign capital, in this study. The result shows that rule of law has a coefficient of 0.0838 , a figure that is significant at the 0.01 level.

The two regressions together provide significant support for the contention that the risk-adjusted return is not a determining factor in the decision by foreigners to invest in a country. It is the quality of institutions, the effective contract enforcement, and the respect for property rights, summed up in the rule of law indicator, that is the driving force for foreign investments is the rule of law.

\section{Summary and Conclusions}

Finance researchers have chronicled quite extensively the benefit of international investment, especially in emerging countries. These researchers have studied less, however, on its impact on the host country. The first part of this paper addresses the host-country effect by analyzing the wealth consequences of foreign investment. The focus on wealth is a departure from the mainstay of existing research, which examines economic growth and other developmental measures.

Using the global market integration scores of a sample of 41 countries and sorting these countries into three portfolios (low-, mid-, and high-integration), we find that countries with highly integrated stock markets have substantially higher income, greater income growth, and higher ownership of natural capital and produced capital. These wealth measures are especially high for the high-integration countries.

Having established a link between high integration and greater wealth levels, this paper next examines the country-specific conditions that foster greater integration. Specifically, it tests the proposition that it is the safety and mobility of foreign capital-rather than the risk-adjusted return-that is the motivating force behind an investor's decision to enter a foreign country. We regress the global stock market integration against the Sharpe Index (a proxy for risk-adjusted return) and against the rule of law indicator (a proxy for the safety and mobility of foreign capital). We find that there is no connection between integration and the Sharpe Index. In contrast, we find very significant association between integration and the rule of law indicator. Taken together, these findings provide support for the contention that foreign investors are motivated chiefly by the quality of the institution, contract enforcement, and respect for property rights.

This paper contributes in two ways to the existing global integration literature. First, it adds wealth and income to the existing list of benefits of foreign investment on the host country. Second, it finds that the risk-adjusted return is not a factor in the decision to invest in a country. It is the ability of the host country to protect foreign capital-the rule of law-that is the driving force behind such a decision.

\section{References}

Akdogan, H. (1996). A suggested approach to country selection in international portfolio diversification. Journal of Portfolio Management, 33-40. http://dx.doi.org/10.3905/jpm.1996.409571

Bailey, W., \& Stultz, R. (1990). Benefits of international diversification: The case of Pacific Basin stock markets. Journal of Portfolio Management, 18, 57-61. http://dx.doi.org/10.3905/jpm.1990.409287

Barari, M. (2004). Equity market integration in Latin America: A time-varying integration score analysis. International Review of Financial Analysis, 13, 649-668. http://dx.doi.org/10.1016/j.irfa.2004.02.019

Bekaert, G., Harvey, C., \& Lundblad. (2005). Does Financial Liberalization Spur Growth? Journal of Financial Economics, 77(1), 3-55. http://dx.doi.org/10.1016/j.jfineco.2004.05.007

Billmeier, A., \& Massa, I. (2009). What drives stock market development in emerging markets-institutions, remittances, or natural resources? Emerging Markets Review, 10, 23-35. http://dx.doi.org/10.1016/j.ememar.2008.10.005

Chelley-Steeley, P. (2004). Equity market integration in the Asia-Pacific region: A smooth transition analysis. International Review of Financial Analysis, 13, 621-632. http://dx.doi.org/10.1016/j.irfa.2004.02.016

Grubel, H. G., \& Fadner, K. (1971). The interdependence of international equity markets. The Journal of Finance, 26, 89-94. http://dx.doi.org/10.1111/j.1540-6261.1971.tb00591.x

Kaufmann, K., \& Mastruzzi. (2008). Governance Matters VII: Aggregate and Individual Governance Indicators, 1996-2007. World Bank Institute. http://dx.doi.org/10.1596/1813-9450-4654 
Lessard, D. (1973). International portfolio diversification; A multivariate analysis for a group of Latin American countries. The Journal of Finance, 28(3), 619-633. http://dx.doi.org/10.1111/j.1540-6261.1973.tb01384.x

Levine, R., \& Zervos, S. (1996). Stock Market Development and Long-Run Growth. World Bank Economic Review, 10(2), 323-339. http://dx.doi.org/10.1093/wber/10.2.323

Levy, H., \& Sarnet, M. (1970). International diversification of investment portfolios. American Economic Review, $60,668-675$.

Sharma, A., \& Seth, N. (2012). Literature review of stock market integration: A global perspective. Qualitative Research in Financial Markets, 4, 84-122. http://dx.doi.org/10.1108/17554171211213568

Solnik, B. H. (1974). Why not diversify internationally? Financial Analyst Journal, 30, 48-54. http://dx.doi.org/10.2469/faj.v30.n4.48

Tswamuno, P., \& Wunnava. (2007). Financial Liberalization and Economic Growth: Lessons from the South African Experience. International Journal of Applied Economics, 4(2), September, 75-89.

World Bank Institute. (2008). Where is the Wealth of Nations? Measuring Capital for the 21st Century.

\section{Notes}

Note 1. For earlier studies documenting the diversification benefits, see Grubel and Fadner (1971), Lessard (1973), Levy and Sarnat (1970), and Solnik (1974).

Note 2. Using CAPM and APT derived integration scores, Levine and Zervos (1996) find no statistically significant between stock market integration and a number of growth indicators, such as output growth, capital stock growth, productivity growth, and savings.

Note 3. See Tswamuno, Pardee, and Wunnava (2007) for the liberalization of the South African capital market.

Note 4. See Chelley-Steeley (2004).

Note 5. See Levine and Zervos (1996).

Note 6. See Bekaert, Harvey, and Lundblad (2004).

Note 7. See Sharma and Seth (2012) for a comprehensive review of the integration literature. Also, see Chelley-Steeley (2004) and Barari (2004).

Note 8. On paper at least, there are more than 42 countries with stock markets, but they are either not active or there are so few stocks traded as not to constitute a market in the traditional sense.

Note 9. The answer to the first question has been well chronicled by finance researchers and will not be addressed in the paper.

Note 10. Kaufmann, Kraay, and Mastruzzi (2008) define the rule of law indicator as a measure the "perceptions of the extent to which agents have confidence in and abide by the rules of society, and in particular the quality of contract enforcement, property rights, the police, and the courts, as well as the likelihood of crime and violence."

Note 11. Kaufmann, Kraay, and Mastruzzi (2008).

\section{Copyrights}

Copyright for this article is retained by the author(s), with first publication rights granted to the journal.

This is an open-access article distributed under the terms and conditions of the Creative Commons Attribution license (http://creativecommons.org/licenses/by/3.0/). 